\title{
La radiación externa controlada como técnica de potenciación de las señales registradas con la termografía infrarroja
}

\author{
External radiation as element of improvement infrared \\ thermography measurements
}

\begin{abstract}
Fecha de recepción: 19-10-99
Fecha de aceptación: 3-01-00

RESUMEN

La termografia infrarroja es una técnica no destructiva, muy versátil, que, entre otras aplicaciones, tiene la de ser capaz de suministrar información en torno a la problemática de las humedades en la edificación. Sin embargo, esta aplicación concreta puede presentar algunos problemas directamente relacionados con las propias características de la termocámara utilizada. En el caso del presente trabajo el equipo de termografia infrarroja manejado trabaja en el rango del espectro IR comprendido entre 2,5 y $5,6 \mu \mathrm{m}$.
\end{abstract}

En esta región del espectro existe una pequeña y no muy intensa banda de emisión de las moléculas de agua (aproximadamente centrada en 2,7 $\mu \mathrm{m}$ ) cuya detección puede no ser fácil a través de la termovisión.

En el presente trabajo se ha desarrollado una técnica complementaria a la termografia infrarroja que es capaz de favorecer la intensidad de emisión del agua en la región del espectro antes mencionada. En definitiva, dicha técnica estimula la capacidad de detección de la termocámara.

Adicionalmente, el proceso hídrico que tiene lugar en el material ha sido numéricamente modelizado.

\section{SUMMARY}

Infrared thermography is a very versatile non destructive technique which among other uses, can be applied to the study of moisture in buildings. However, this particular application can present some problems strictly related to the characteristics of the thermocamera device. In this case the available equipment works in the IR range of 2.5 to $5.6 \mu \mathrm{m}$.

In this part of the spectrum, there exists a small and not very intense band of emission of the water molecules (aproximately centred at $2.7 \mu \mathrm{m}$ ), in such a way that detection can be difficult through thermovision.

In the present paper, a complementary technique to the IR thermography being able of favouring the emission of water on the mentioned band, has been developed. It enhances the capacity of detection of the instrument.

Likewise, the process which takes place in the material has been numerically modelled.

\section{INTRODUCCIÓN}

Dentro del campo de la conservación y restauración de los edificios históricos, la humedad es considerada como uno de los problemas mas frecuentes a estudiar y

\section{INTRODUCTION}

In the field of maintenance and repair of historic building, humidity is one of the most frequent problems to be studied and solved. Due to the 
a resolver. Debido a las condiciones medioambientales (clima contaminación, etc.) y también a la complejidad de los materiales y de los procesos que se desarrollan en su interior, la aparición de agua en un lugar determinado de un edificio no siempre puede relacionarse con la causa que origina el problema. Sin embargo, un plan razonable de restauración debe contemplar entre sus principales objetivos el conocimiento de dichas causas. Además, teniendo en cuenta que el objeto de nuestra preocupación (edificios históricos) posee, culturalmente hablando, un valor ilimitado, parece obvio resaltar la importancia que tiene trabajar con técnicas de estudio no destructivas. En este sentido, la termografia IR se presenta con un gran potencial en su aplicación a la resolución de problemas como el planteado.

La termografia IR es una técnica no destructiva que permite medir la radiación emitida por los objetos en un rango específico de longitud de onda (entre $2,5 \mu \mathrm{m}$ y 5,6 $\mu \mathrm{m}$ en este caso concreto). Esta radiación está intimamente ligada con dos propiedades físicas de los materiales: emisividad y temperatura superficial (1-4).

En el terreno de la edificación, se han desarrollado varias aplicaciones de la termovisión como el estudio de puentes térmicos, materiales aislantes, etc. En este tipo de aplicaciones, la variación de la radiación emitida por un objeto se correlaciona con su temperatura superficial puesto que se asume que la emisividad es una constante independiente de los cambios térmicos producidos en el objeto (4-6).

Sin embargo la utilización de la termografía IR para detectar humedades en los edificios, presenta algunos inconvenientes que conviene destacar. Por un lado, la variación del contenido de agua en el material implica modificaciones de la temperatura superficial del mismo y también de la emisividad. Por otro lado, teniendo en cuenta que nuestro objetivo último es el aplicar la técnica en situaciones reales de medidas de humedad, es importante no olvidar la existencia de un grupo de parámetros que afectan considerablemente a las medidas in situ, como, por ejemplo, el factor de forma, la atenuación atmosférica, la radiación externa, etc.; todos ellos, factores que ya han sido estudiados por diferentes autores (7-12).

Existe otro tipo de problemas, también relacionados con la investigación que aquí se describe y que tienen que ver con el tipo de termocámara utilizada:

Entre las bandas de emisión del agua, precisamente la más intensa cae fuera del rango de detección de nuestro equipo; consecuentemente sería de gran interés poder potenciar aquellas bandas de emisión que caen dentro del rango específico de detección de nuestra external conditions as well as the complexity of materials and processes, the appearing of water in a particular place can not always be related with the origin of the problem. However, the knowledge of this origin must be one of the main objectives when a plan of restoration is going to be carried out. Taking in consideration the field of science we are working in (cultural heritage), it is obvious the importance of accounting with non destructive methods for studying materials. IR thermography is showing to have an enormous potential for being applied to problems like the ones here approached.

IR thermography is a non destructive technique for measuring the radiation emitted by objects in a specific range of length of wave (between $2.5 \mu \mathrm{m}$ and $5.6 \mu \mathrm{m}$ for this particular case). This radiation is narrowly related with two physical properties of materials: emisivity and surface temperature (1-4).

In building science, several methods based on this technique have been developed in order to study problems like continuity of thermal isolating materials, thermal bridges, etc. In this kind of work, the variation of radiation emitted by an object is identified with its surface temperature as emisivity is assumed to be constant and independent of the temperature changes produced in this object (4-6).

However, the utilisation of IR thermography for detecting and measuring moisture in buildings presents some inconvenient. On one hand, the variation of water content in the material involves changes in the surface temperature and in the emisivity. Additionally, taking in consideration that our final objective is to apply of the technique to the detection of moisture in buildings, it is important to consider a list of parameters considerably affecting the "in situ" measurements; for example: shape factor, atmospheric attenuation, external radiation, etc. All these factors have deeply studied by a number of authors (7-12). Sometimes, the method of measurement has been even modelled.

There exists another problem, concerning this kind of work, which is basically related with the characteristics of the available thermocamera.

The strongest band of emission of water is out of the detection range of the thermocamera; consequently it is of major interest to enhance the bands of emission of water in that particular area of the IR 
termocámara $(2,5 \mu \mathrm{m}$ a $5,6 \mu \mathrm{m})$. Es por ello que se ha desarrollado una técnica basada en el uso de fuentes de radiación externa como método de estimular las señales recogidas por la termografía IR. La excitación de áreas húmedas por medio de esta técnica, favorece la emisión del agua y permite una mejor detección de dicho líquido a través de la termovisión.

El agua tiene una pequeña banda de emisión centrada en 2,7 $\mu \mathrm{m}$. De acuerdo a la ley de Kirchoff si una radiación incide sobre una superficie húmeda, la señal recogida por la termocámara (emitida +reflejada) aumentará con respecto a la radiación emitida por el objeto.

En la Figura 1 se muestra la exitancia radiante de un cuerpo negro a diferentes temperaturas. Se puede ver que un aumento en la temperatura de la superficie del objeto estimula la detectabilidad por medio de la termografia.

Existen dos formas de medir las variaciones térmicas de un objeto. Por un lado, cualquier calentamiento real implicará un aumento de temperatura. Además, la incidencia de cualquier radiación externa reforzará la radiación total recibida por la termocámara. Si dicha radiación solamente produce una reflexión sobre la superficie del objeto, entonces el análisis termográfico mostrará un incremento aparente de la temperatura.

R. Shickert $(14,15)$ comenzó a aplicar un método similar para la detección (por medio de la termografía IR) de algunos tipos de alteraciones en materiales de construcción. Basándose en esta técnica el mencionado spectrum (2.5 $\mu \mathrm{m}$ to $5.6 \mu \mathrm{m})$ ). It is for this reason that a technique based in the use of external radiation sources has been developed. The excitation of wetted areas by mean of this technique, favours the emission of water, allowing a better detection of the liquid through IR thermography

Water has a small band of emission centred in $2.7 \mu \mathrm{m}$. According to the Kirchoff's law, if a radiation falls in a wetted surface, the signal received by the thermocamera (emitted + reflected) will be increased with respect to the radiation emitted by the object.

In Figure 1, the radiant excitance is shown for different temperatures of a black body. It can be seen that an increase of the temperature of the object surface will enhance the detectability by $I R$ thermography.

There exist two ways for measuring the thermal variation of an object. On one hand, any real heating will involve a temperature increase. Besides, the incidence of some specific external radiation will strengthen the total radiation received by the thermocamera. If such radiation only produces a reflection on the surface object, the thermographical analyses will show an apparent increase of the temperature.

$R$. Shickert (14 and 15) started to apply a similar method for the detection (by mean of the IR thermography) of some kind of alterations in building materials. Based on this technique, the mentioned author got good results

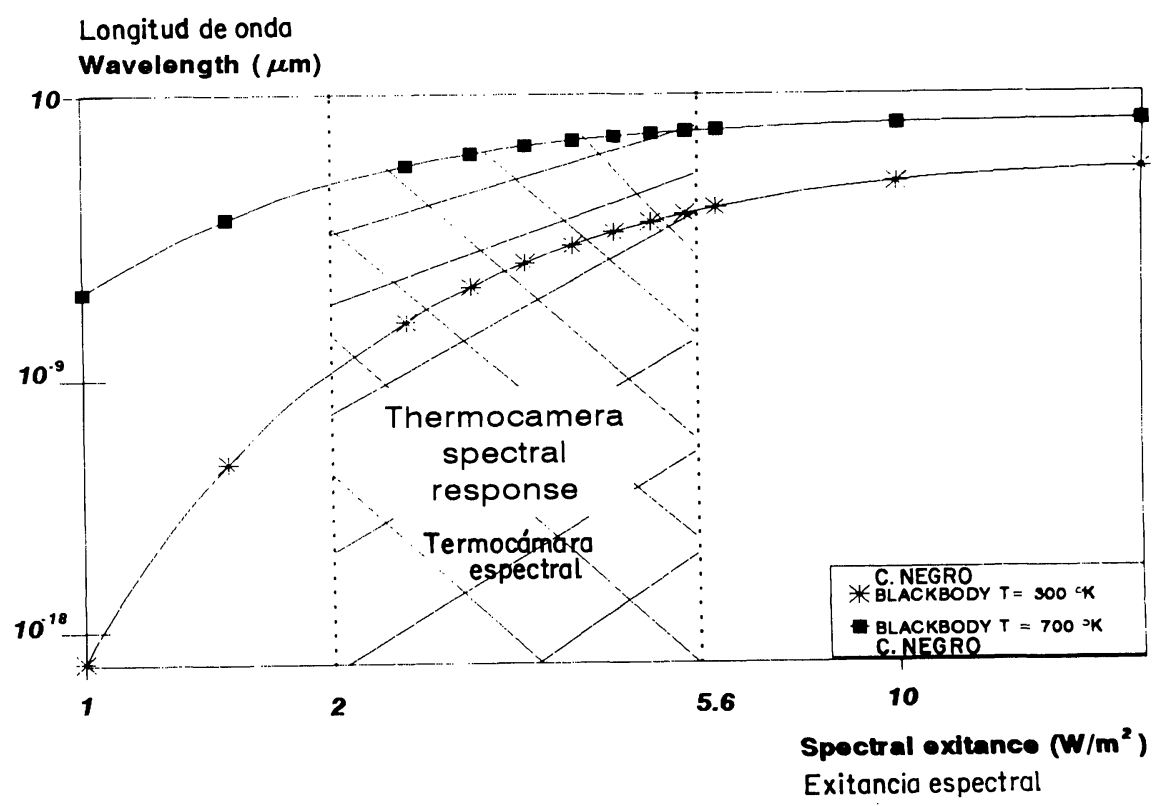

Figura 1.- Exitancia radiante.

Figure 1.- Radiant exitance 
autor obtuvo buenos resultados en el estudio de frescos que se suponía habían sido pintados sobre otras pinturas.

\section{EXPERIMENTACIÓN Y RESULTADOS}

\section{Modelización del proceso}

Consideremos un material de emisividad conocida $(\varepsilon)$ que se encuentra saturado de agua hasta $1 / 2$, siendo I la longitud del objeto. Simultáneamente asumimos que el material posee una porosidad "v" y que todos los poros tienen forma esférica y se encuentran homogeneamente distribuidos. La radiación emitida por el objeto se mide con la termocámara en diferentes puntos prefijados (ver Figura 2).

Se considera que el punto mas alto está seco. Además, cualquiera de esos puntos prefijados se supone que están suficientemente alejados de la zona de transición como para no verse afectados por el gradiente de temperatura que produce el fenómeno de la capilaridad. Adicionalmente, ninguna radiación externa (excepto la proveniente de nuestra fuente) está en contacto con el material.

Los siguientes casos serán tomados en consideración:

*Antes de que la radiación externa comience a trabajar studying frescoes which were supposed to be painted on former paintings.

\section{EXPERIMENTAL AND RESULTS}

\section{Modelling of the process}

A material with well known emissivity $(\varepsilon)$ is considered. It is saturated with water until $1 / 2$ being $l$ the length of the object. Assuming the material has a porosity of " $v$ "; being all the pores homogeneously distributed and spherically shaped. The radiation emitted by the object is measured with the thermocamera in different fixed points (see Figure 2).

The top point is considered to be dry. Besides, any of the considered points it is supposed to be far enough from the transition zone (dry/wet) for not being affected by the temperature gradient produced by the capillarity phenomenon. Additionally, none external radiation (except the one from the source) is touching the material.

Two cases will be taken into account:

* Before the external radiation start to work

$$
\begin{gathered}
E_{b}=\varepsilon(1-v) I_{b}=K_{b} I_{b} \\
E_{a}=\varepsilon(1-v) I_{a}+v_{w} I_{a}=K_{a} I_{a}
\end{gathered}
$$

*Mientras que la radiación externa está trabajando

* When the external radiation is working

$$
\begin{gathered}
E_{b}=\varepsilon(1-v) I_{b}+(1-\varepsilon)(1-v) R=K_{b} I_{b}+K_{b} R \\
E_{a}=\left(\varepsilon(1-v)+v \varepsilon_{w}\right) I_{a}+\left((1-v)(1-\varepsilon)+v\left(1-\varepsilon_{w}\right)\right) R K_{a} I_{a} K_{a} R
\end{gathered}
$$

Donde:

$\mathrm{E}_{\mathrm{b}}$ y $\mathrm{E}_{\mathrm{a}}$ son respectivamente las energías radiadas por los puntos "seco" y "húmedo" del material.

$\varepsilon$ es la emisividad del material.

$\varepsilon_{\mathrm{w}}$ es la emisividad del agua.

$\Delta \mathrm{I}_{\mathrm{a}}$ e $\Delta \mathrm{I}_{\mathrm{b}}$ son las energías emitidas por un cuerpo negro (seco y mojado) con iguales características que el material.

La diferencia de energía $E_{i}$ entre las partes seca y húmeda o entre las partes irradiadas y las no irradiadas, son medibles a través de la termografía.
Where:

$E_{b}$ and $E_{a}$ respectively are the energies radiated by the dry and wetted points from the surface.

$\varepsilon$ is the emissivity of the material.

$\varepsilon_{w}$ is the emissivity of water.

$\Delta I_{a}$ and $\Delta I_{b}$ are the energies emitted by a black body (dry and wetted) with equal characteristics to the material.

The difference of energy $E_{i}$ between dry and wet parts or between radiated and non radiated parts, are measurable through thermography. 
Partiendo de las ecuaciones (1) y (4) se puede obtener la siguiente línea recta:
Starting from equations (1) and (4) the following theoretical straight line can be obtained:

$$
\Delta \mathrm{I}_{\mathrm{b}}=\frac{\mathrm{B}_{\mathrm{o}}}{\mathrm{K}_{\mathrm{b}}}-\frac{\mathrm{D}_{\mathrm{o}}}{\mathrm{K}_{\mathrm{a}}}+\frac{1-\varepsilon}{\varepsilon} \frac{\varepsilon+\mathrm{v}\left(\varepsilon_{\mathrm{w}}-\varepsilon\right)}{(1-\varepsilon)+\mathrm{v}\left(\varepsilon-\varepsilon_{\mathrm{w}}\right)} \Delta_{\mathrm{a}}
$$

Donde:

$\mathrm{B}_{\mathrm{o}} \mathrm{y} \mathrm{D}_{\mathrm{o}}$ son respectivamente las diferencias de energía detectadas por la termocámara, tanto en el material seco como en el húmedo, antes y durante la radiación.

$\mathrm{K}_{\mathrm{b}} \mathrm{y} \mathrm{K}_{\mathrm{a}}$ son constantes relacionadas con la porosidad $\mathrm{y}$ la emisividad en las partes seca y húmeda del material.

$\varepsilon$ es la emisividad del material.

$\varepsilon_{\mathrm{w}}$ es la emisividad del agua

$\Delta \mathrm{I}_{\mathrm{b}}$ y $\Delta \mathrm{I}_{\mathrm{a}}$ son respectivamente las energías emitidas por el objeto seco y húmedo.

Las pendientes de las líneas están relacionadas con la porosidad "v" del material mediante:

$$
\mathrm{v}=\frac{(\mathrm{m}-1)(1-\varepsilon) \varepsilon}{\left(\varepsilon-\varepsilon_{\mathrm{w}}\right)(1-\varepsilon-m \varepsilon)}
$$

Donde:

m es la pendiente

$\mathrm{v}$ es la porosidad

$\varepsilon$ es la emisividad.

$\varepsilon_{\mathrm{w}}$ es la emisividad del agua
Where:

$m$ is de slope

$v$ is the porosity

$\varepsilon$ is the emissivity of the material

$\varepsilon_{w}$ is the emissivity of water.

\section{Experimental verification of the model}

In this kind of tests, it is important not to produce a real change in the temperature of the material when the external radiation is working. It has been experimentally shown that a brick subjected to the action of an external, controlled, radiation does not involve a real heating of the surface of the object. The test was carried out on a brick saturated with water until the middle (characteristics of tested bricks are shown in Table I). The source of radiation was perpendicularly fitted to the black surface and slightly behind of the thermocamera in order to avoid the incidence of some radiation on it (see Figure 3). 
TABLA I (TABLE I)

Catacterísticas de los ladrillos estudiados (Characteristics of tested bricks)

\begin{tabular}{||c|c|c|c|}
\hline $\begin{array}{c}\text { Porosidad accesible al } \\
\text { agua (\%) } \\
\text { (P. acc. } \text { to } \text { water (\%)) }\end{array}$ & $\begin{array}{c}\text { Porosidad total por Hg } \\
\text { (Mercury porosity (\%)) }\end{array}$ & $\begin{array}{c}\text { Altura (cm) } \\
\text { Height (cm)) }\end{array}$ & $\begin{array}{c}\text { Puntos medidos } \\
\text { (Measured points) }\end{array}$ \\
\hline $28,29 \pm 0,03$ & $21,98 \pm 0,03$ & 29 & 5 \\
\hline
\end{tabular}

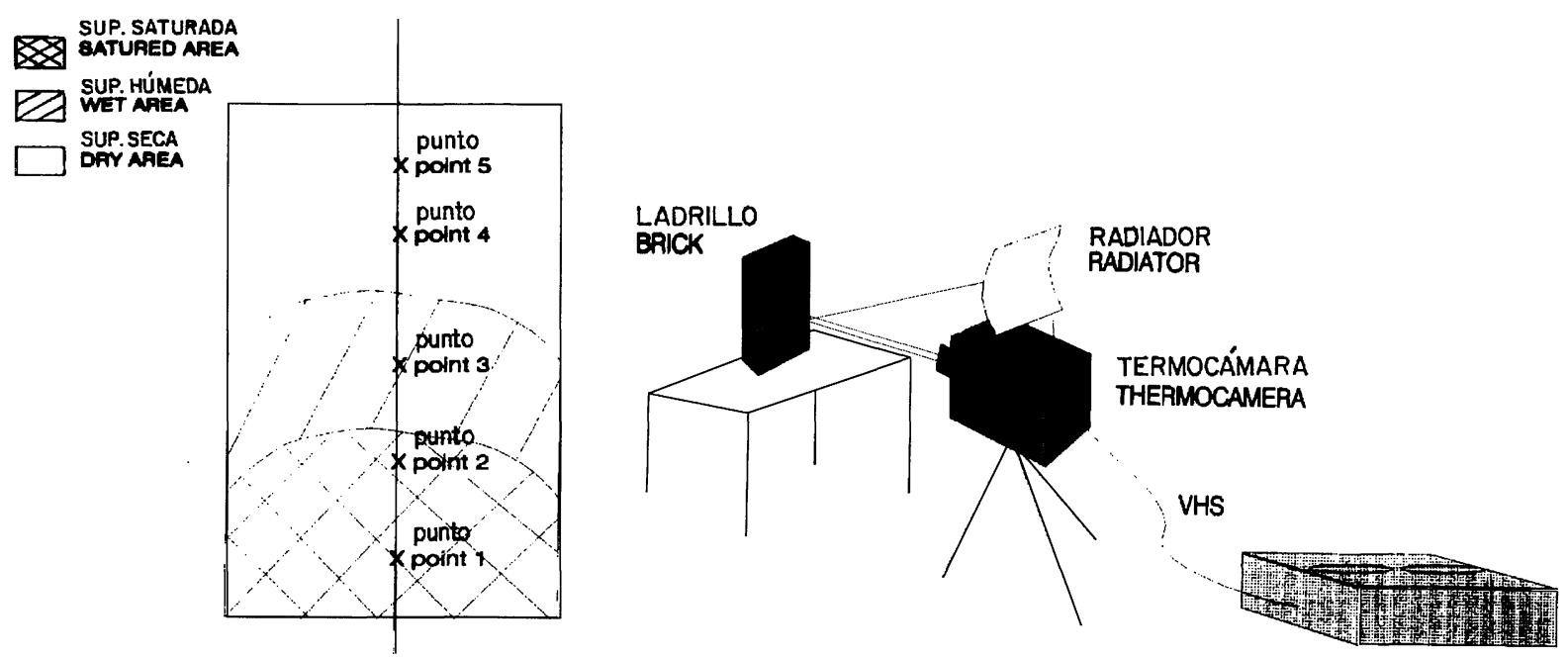

Figura 2.- Representación esquemática de la muestra ensayada

Figure 2.- Schematic representation of the sample test.
Figura 3.- Lisquema del experimento.

Figure 3.- Scheme of the experiment.
La radiación total recibida por la termocámara procedente de diversos puntos del material situados a diferentes alturas (siempre sobre el eje central) se midió antes y durante la incidencia de la radiación. En la Figura 4 se pueden ver los resultados.

La intensa caída de la radiación que se produce cuando se desconecta la fuente, demuestra experimentalmente el no incremento de temperatura en la superficie del material durante la radiación.

De las ecuaciones (5) y (6), se obtiene la porosidad aparente del material en todos los puntos. Los resultados se muestran en 5,6 y 7 .

Los valores obtenidos para la porosidad aparente deberían estar relacionados con el contenido de agua en cada punto, lo que significa que por medio de esta técnica es posible seguir la evolución del agua en el material sobre diferentes puntos de su superficie y también sobre un único punto a lo largo del tiempo.
The total radiation received by the thermocamera in points situated at different heights (on the central axe) was measured before and during the incidence of the radiation. In Figure 4, results are shown.

The sharp fall of the radiation when the source is switched off, experimentally shows the no increase of temperature of the material during the radiation.

From equations (5) and (6), the apparent porosity, for all points, is obtained. Results are shown in figures 5, 6 and 7 .

The values obtained for the apparent porosity should be correlated to the water content in each point. It means that by mean of the used technique it is possible to follow the evolution of water in the material on different points of the surface and also on one only point along the time. 


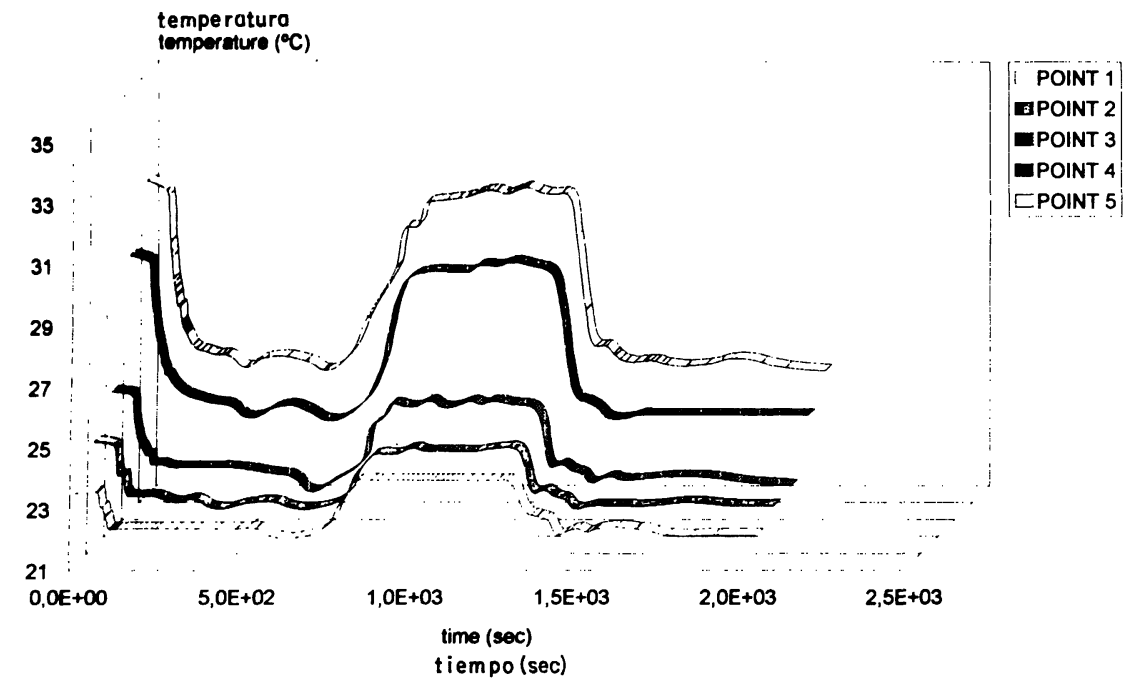

Figura 4.- Radiación total recogida por la termocámara.

Figure 4.- Total radiation recieved by the thermocamera.

\section{DISCUSIÓN}

Uno de los problemas más importantes relacionados con la aplicación de la termografía IR a la localización de áreas húmedas en edificios es el de la detección de zonas con bajos contenidos de agua. El problema se complica si la termocámara tiene un rango de detección limitado (entre 2,5 y 5,6 $\mu \mathrm{m}$ ) como es nuestro caso. En dichas circunstancias no se puede detectar la principal banda de emisión del agua centrada en $6 \mu \mathrm{m}$. Sin embargo si se podría detectar la pequeña banda que también tiene el agua en $2,7 \mu \mathrm{m}$. Si un objeto húmedo se somete a una radiación con esa frecuencia, de manera que sólo se produzcan reflexiones en la superficie, entonces la termocámara recibirá una radiación total (captará una señal) notablemente potenciada.

Los resultados que se presentan en la Figura 3 muestran zonas de ladrillo secas (áreas en las que el material se encuentra a la máxima temperatura del sistema) que están sufriendo aparentes incrementos de temperatura (mayores que los que sufren las áreas húmedas). Puesto que el volumen de poros se considera que está homogéneamente distribuido y puesto que la fuente de radiación externa está situada perpendicularmente a la superficie estudiada, el fenómeno observado debería explicarse por la mayor capacidad del material respecto del agua, a reflejar la radiación. En consecuencia una fuente externa de radiación produce una separación entre la señal que genera el material seco y la que genera el mismo material ligeramente mojado.

Finalmente, en dicha Figura 3 se observa que las variaciones agudas de la temperatura coinciden con el momento en que se conecta la fuente de radiación

\section{DISCUSSION}

One of the most important problems related to the application of the IR thermography in the detection of wetted areas of building materials, is the study of zones with low content of moisture. This problem is more complicated if the available thermocamera has a detection range between 2.5 and $5.6 \mu$ m (like the one used in this investigation), because the main band of emission of water is centred in $6 \mu \mathrm{m}$. However, water also has a small band around $2.7 \mu \mathrm{m}$. If a wetted object is subjected to a radiation with this frequency in such a way that only reflections are generated in the surface, an increase of the total radiation received by the thermocamera will be produced.

Results presented at Figure 3 shows dry zones of bricks (areas with the highest initial temperatures) undergoing higher increases of the apparent temperature than the wetted areas. Since the volume of pores is considered homogeneously distributed and the external source is situated perpendicular to the studied surface, the observed phenomenon should find an explanation in the better capacity of the material, with respect to water, for reflecting the radiation. Consequently an external source of radiation produces a separation between the signal from dry material and from slightly wetted material.

Finally in this figure, sharp variations of temperature coinciding with the time at which the source of radiation was switched on (700 sec.) and off (1.700 sec), can be 
(700 segundos) y con el que esta se desconecta (1.700 segundos). Estas variaciones demuestran que la lámpara no produce un calentamiento real del objeto ya que esto implicaría una situación asociada a una curva exponencial.

El modelo matemático del proceso se basó en el estudio de la variación de la radiación total recibida por la termocámara en dos situaciones opuestas:

\section{. No existe radiación externa}

. Una radiación externa de características conocidas incide sobre la superficie objeto de estudio.

En todos los ensayos realizados utilizando la radiación externa, se consideró que el punto más alto de la muestra estaba completamente seco. En la Figura 5 se observan las líneas obtenidas para cada uno de los puntos analizados cuando se aplica la ecuación (5). Como se deduce del modelo matemático previamente establecido, el valor de la pendiente de estas líneas está relacionado con el contenido de agua del material

En el modelo se considera que la radiación total procedente de una parte concreta del material es la radiación emitida por el material más la emitida por el agua contenida en el sistema poroso. La emisividad del aire no ha sido tomada en consideración y, por tanto, la cantidad de agua existente en una zona concreta del material se puede calcular a través del valor de la porosidad aparente " $v$ "; es decir, se considera que el material tiene una porosidad aparente " $\mathrm{v}$ " que decrece gradualmente desde el interior hacia la superficie. Cuantificar "v" debe ser, por lo tanto, equivalente a evaluar el contenido de agua en la superficie del material. De la misma manera, haciendo un seguimiento del contenido de agua en el material, se podría conocer la porosidad del material. observed. These variations show that the radiation lamp does not produce a real heating of the object because a real heating would involve an exponential curve.

The mathematical model of the process was based in the study of the variation of the total radiation received by the thermocamera in two opposite situations.

\section{. There not exists external radiation. \\ - A external radiation having known characteristics, works on the surface to be studied.}

In all the tests carried out with external radiation, the top point of the specimen was considered to be completely dry. Figure 5 shows the lines obtained for each of the points analysed when equation (5) is applied. As it can be deduced from the mathematical model previously established, the value of the slope of these lines is correlated to the water content of the material.

In the model, the total radiation from a specific part of the material is considered to be the total energy emitted by the material plus the energy emitted by water in porous system. The emissivity of the air has not been considered and then, the water content existing in a particular area of the material is quantified from a value of apparent porosity " $v$ ", that is to say, the material is considered to have an apparent porosity " $v$ " which gradually decreases in the surface of the material. Therefore the quantification of " $v$ " must be equivalent to the evaluation of a water content in the material surface. Likewise, following the evolution of the water content in the material, it would be possible to know the material porosity.

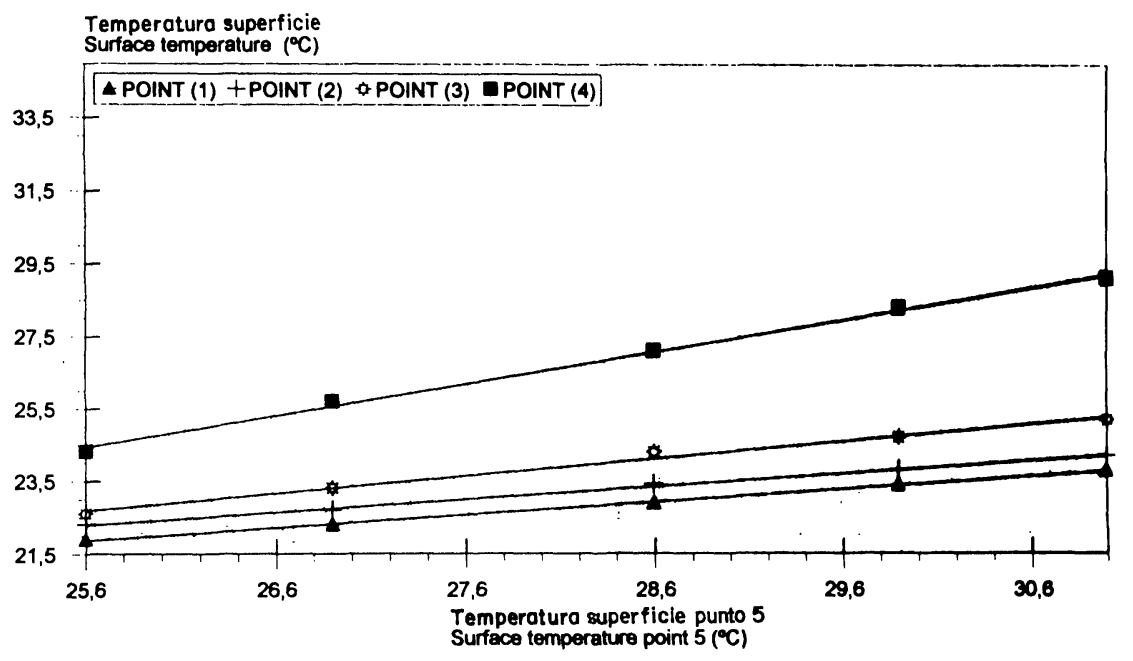

Figura 5.- Líneas obtenidas para cada punto analizado al aplicar la ecuación (5).

Figure 5.- The experimental lines obtained through equation (5) can be seen. 
En la Figura 5, se pueden ver las líneas experimentales obtenidas a través de la ecuación (5). Para obtener dichas líneas se ha considerado que el punto mas alto de la muestra estudiada estaba completamente seco.

El punto $\mathrm{n}^{\circ} 4$ demuestra tener unas características diferentes al resto. Ello significa que el contenido de agua en esa zona es bajo.

La evolución en el tiempo del contenido de agua en cada una de las zonas del material, puede seguirse en la Figura 6. Inicialmente los puntos situados en la parte inferir de la muestra objeto de estudio (a 5 y a $7,7 \mathrm{~cm}$ de altura) absorben una cierta cantidad de agua, que procede del interior del material, hasta que se alcanza la saturación. Después de 70 minutos comienza un proceso por el cual se pierde agua. Las curvas corresponden, como se demostrará, a un proceso de evaporación. Además, dichas curvas se ajustan a los resultados teóricos obtenidos a través de los modelos previamente descritos. El punto situado a $15 \mathrm{~cm}$ de altura, considerado seco, absorbe agua procedente de la parte inferior hasta que se alcanza el equilibrio. Si en ese momento se analiza la cantidad de agua en equilibrio, se puede observar que el agua intenta permanecer en las zonas centrales de la superficie del material ( 7,75 y $15 \mathrm{~cm}$ de altura). Esos son los puntos que presentan la máxima cantidad de agua al final del análisis.

En la Figura 7 se representa la evolución de la humedad en función de la altura del material. Inicialmente, existe un gradiente de agua en la superficie del material (observar la curva en el punto correspondiente al minuto 0 ). Posteriormente se produce un redistribución del agua en la superficie de la muestra; aparece una zona saturada (hasta $8 \mathrm{~cm}$ de altura) y simultáneamente el agua comienza a alcanzar el punto inicialmente seco (aproximadamente a $15 \mathrm{~cm}$ ). Se puede comprender que esta redistribución del agua en la superficie del material es debida, fundamentalmente, al peso de la columna de agua.
In Figure 5, the experimental line obtained through equation (5) can be seen. For the obtaining of the lines, the top point or the specimen has been considered to be completely dry.

Point 4 shows different characteristics with respect to the rest. It means that in this zone the water content is low.

The evolution of the water content with time, for each zone of the material can be seen in Figure 6. Initially, the points situated at the bottom of the specimen ( 5 and $7.7 \mathrm{~cm}$ height) absorb a certain amount of water coming from inside of the material until saturation is reached. After 70 minutes a process of water loss starts. These curves correspond, as it will be demonstrated, with the weight loss of the material in an evaporation process. Additionally, they are fitted to the theoretical results obtained through the models previously described. The point situated at $15 \mathrm{~cm}$ height, considered to be dry, absorbs water from the bottom until equilibrium is achieved. If now the content of water in equilibrium is analysed, it can be observed the water trying to remain in the central zones of the surface of material 7.75 and $15 \mathrm{~cm}$ height). They are the points presenting the maximum content of water at the end of the analysis.

The evolution of humidity with the height of the material is presented in figure 7. Initially, there exists a gradient of the water content in the surface of the material (see the curve corresponding to minute 0). After that, a redistribution of water in the surface of the specimen is produced; a saturated zone appears (until $8 \mathrm{~cm}$ height) and simultaneously the water begin to reach the point initially dry (around $15 \mathrm{~cm}$ ). It can be understood that this redistribution of water in the surface of the material is mainly due to the weight of the water column.

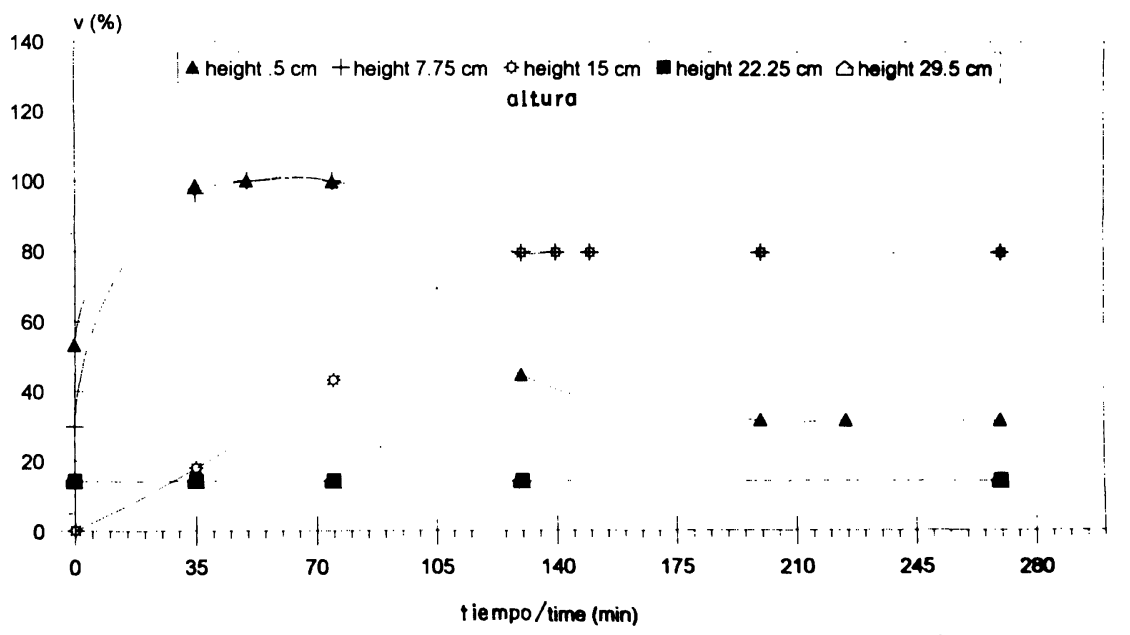

Figura 6.- Evolución del contenido de agua en función de la zona del material.

Figure 6.- Evolution of the water content with time for each zone of the material. 


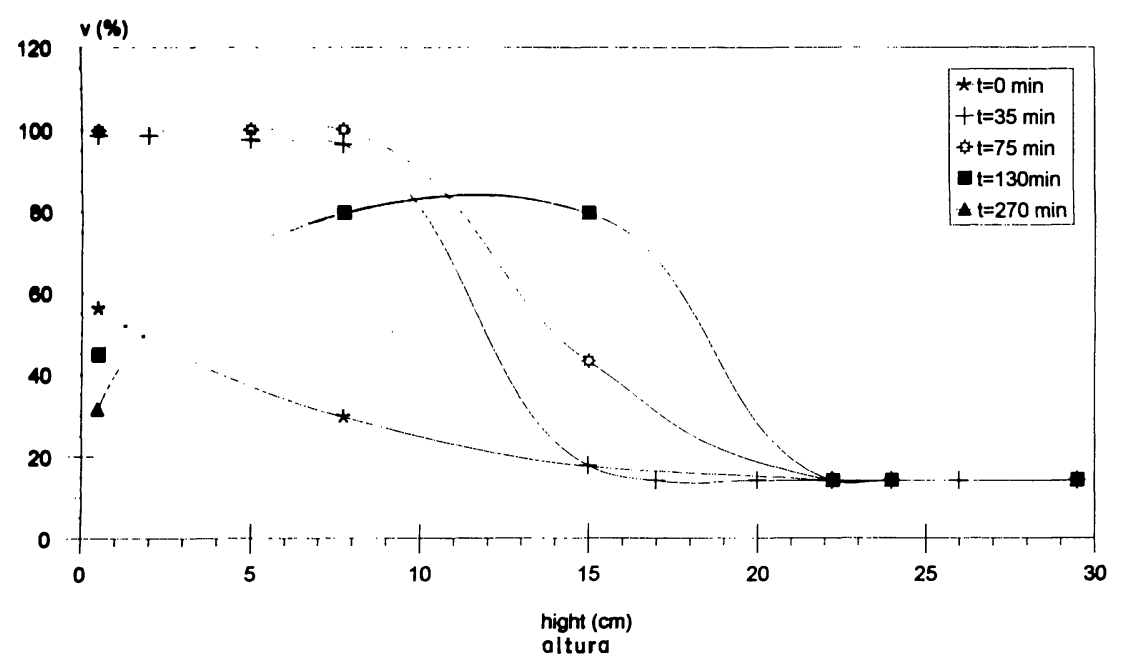

Figura 7.- Evolución de la humedad en función de la altura del material.

Figure 7.- Evolution of humedity with the height of the material.

Si se estudian las curvas correspondientes a momentos posteriores, se puede ver que el agua tiende a mantenerse en las zonas centrales de la superficie del material. Por un lado existe un movimiento capilar del agua hacia las zonas secas (observar el incremento en el contenido de agua a la altura de $15 \mathrm{~cm}$ ). Por otro lado, existe una pérdida de agua en la parte inferior del material que se puede explicar por el aumento de la superficie de ventilación en esa zona específica (el agua evapora por la base del material y por el resto de las caras).

\section{CONCLUSIONES}

La utilización de la termografía IR para la detección de humedad en materiales de construcción presenta algunos inconvenientes relacionados con al calidad de la imagen obtenida. El problema se hace mas ostensible cuando el contenido de agua es relativamente bajo. El uso de fuentes externas de radiación permite mejorar esa desventaja concreta de la termovisión sin perturbar el estado del material.

Partiendo de un modelo matemático, desarrollado durante la investigación, es posible obtener información sobre la cantidad de agua en cada punto de la superficie del material así como el modo en que se mueve el líquido por el material a lo largo del tiempo.
If the curves corresponding to posterior times are studied, it can be seen that water tends to maintain in the central zone of the surface of material. On one hand there exists a capillary movement of water towards the dry zone (see the increase of the water content around $15 \mathrm{~cm}$ height). Additionally, there exists a loss of water in the bottom part of the material which can be explained for the increase of the surface of ventilation in this particular zone (the material evaporates through its base together with the other faces).

\section{CONCLUSIONS}

The utilisation of IR thermography for the detection of moisture in building materials presents some inconvenient related to the quality of the image obtained. It is specially marked when the materials have low contents of water. The use of external sources of radiation allow to improve that particular disadvantage of thermovision without disturbing the state of the material.

Starting from a mathematical model, developed during the investigation, it is possible to obtain information about the amount of water in each point of the material surface as well as the from of the movement of the liquid along the time.

\section{BIBLIOGRAFÍA}

(1) D. R. Hudson Jr. "Infrared System Engineering" Ed: John Wiley and Sons. New York (1969).

(2) G. Gaussorgues "La Thermographie Infrarouge. Principes Technologies-Applications". Technique et Documentation. Ed.: Lavoisier (1989).

(3) "The Infrared Hanbook". Editores: W. L. Wolfe y G. J. Zissis. Ed.: Environmental Research Institute of Michigan (1989).

(4) B. Petterson, B. Axén "Thermography. Testing of a Thermal Insulation an Airghtness of Buildings". Editor: Bengt Steen. Ed.: Swedish Council of Building Research, Stockholm(1980). 
(5)S. F. Burch, J. T. Burton, S. J. Cocking "Detection of defects by transient thermography: A comparation of predictions from two computer codes with experimental results". British Journal of NDT. pp. 36-44 (1984).

(6)S. Allen, L. R. Allen "Development of Infrared Thermography standards for New Jersey state buildings". SPIE vol. 581 Thermosense VIII pp 156-161 (1986).

(7)E. Gayo, A. Palomo, A. Macías "La termografia Infrarroja: Posibilidades y aplicación al estudio de superficies de materiales" Revista de Materiales de la Construcción, vol. 42, pp. 5-14 (1992).

(8)E. Gayo, A. Palomo, A. Macías "Infrared thermography as a tool for studing the movement of water throught some building materials. Part I: capillar moisture". The European Journal of NTD, vol. 2, pp. 159-166 (1993).

(9)E. Gayo, A. Palomo, A. Macías "Infrared thermography as a tool for studing the movement of water throught some building materials. Part II: evaporation test”. The European Journal of NDT, vol. 3, pp. 55-58 (1993).

(10)E. Gayo "La humedad como causa de palologías en monumentos: desarrollo de nuevas técnicas de análisis no destructivo basadas en termografia infrarroja". Tesis Doctoral. Universidad Complutense de Madrid (1995).

(11)E. Ishikawa "Some laboratory tests on application of thermography to no destructive testing of building materials and structures". Proceedings of the $6^{\text {th }}$ International Conference Held. Durability of Building Materials and Components, vol. 2, pp. 883-892, Omiya (Japóm) (1993).

(12)C. Martín, G. Villoutreix, P. Fauchais, J. Martinet "Utilization de la thermographic infrarouge por la mesure du facteur normal d'ćmission de métaux dans une spectrale de largeur déterminée". C. R. Acad. Sc. Paros t. 25 (1972)

(13)"AGA Thermovision 82. Operating Manual". AGA Infrared System (1981).

(14)R. Schickert "Infrared thermography as a possible tool to detect damaged areas in buildings. Durability of buildings materials, Vol. 3, pp. 87-99(1985).

(15)R. Schickert, B. Bottcher "Application of IR thermography to investigate damage areas of buildings". Proccedings of the International Colloquia Materials Science and Restoration, pp. 1-7, Nellingen. Alemania (1983).

\section{publicaciones del IETCC/CSIC}

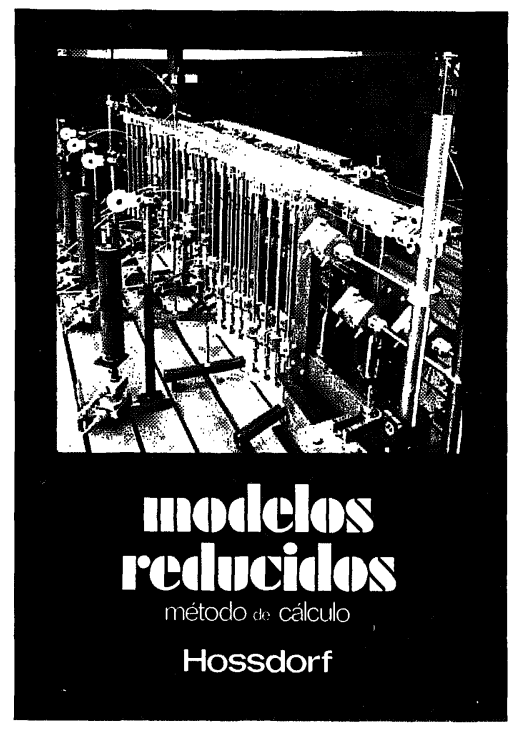

Modelos reducidos. Método de cálculo

H. Hossdorf, Ingeniero Civil

La técnica de los ensayos en modelos reducidos de estructuras sufre hoy dia una decisiva metamorfosis. Hasta hace poco era un medio más bien de artesania, que no siempre era tomado en serio por los académicos teorizantes Dara comprender el comportamiento resistente de las estructuras complejas y a que se acudió las más de las veces, como a un último remedio debido a sus indiscutibles insuficiencias. Sin embargo, en poco tiempo y gracias a su conexión con los ordenadores digitales, se ha trans formado en un instrumento cientificamente valioso que no puede quedar a un lado en la práctica diaria del Ingeniero Proyectista.

Un volumen encuadernado en cartoné plastificado con lomo de tela, de $17 \times 24 \mathrm{~cm}$, compuesto d 250 páginas, 158 figuras y fotografias.

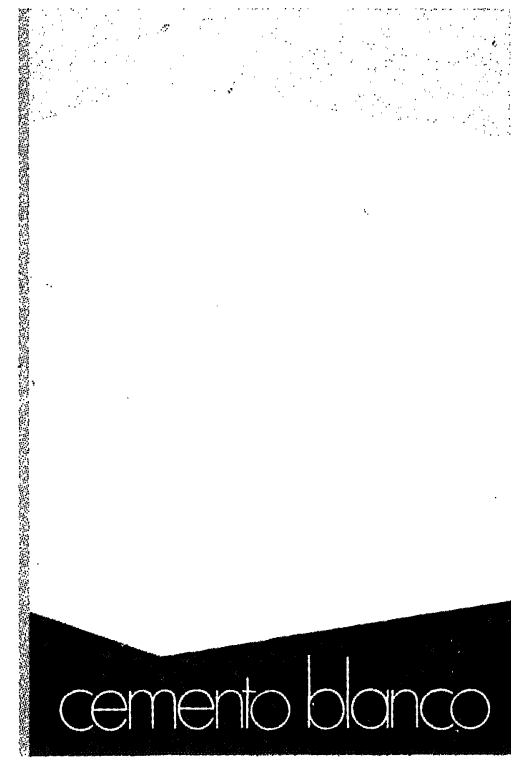

Cemento blanco

Juliản Rezola

Ingeniero Quimico Dipl. I. O. S.

Sabido es que existe una extensa y documentada bibliografia sobre el cemento gris: en cambio, no puede decirse lo mismo acerca del cemento portlan sólo a algunas peculiaridades que le distinguer de aquée.

El autor nos ofrece sus profundos conocimientos y su larga experiencia tanto en laboratorin como en fabricacion.

La parte descriptiva del libro se complementa con gráficos, diagramas y fotografias de gran utilidad destinados a consequir la aplicación apropiada de este aglomerante.

Un volumen encuadernado en cartoné policerado, de $17,4 \times 24,3 \mathrm{~cm}$, compuesto de 395 páginas, numerosas figuras, tablas y ábacos.

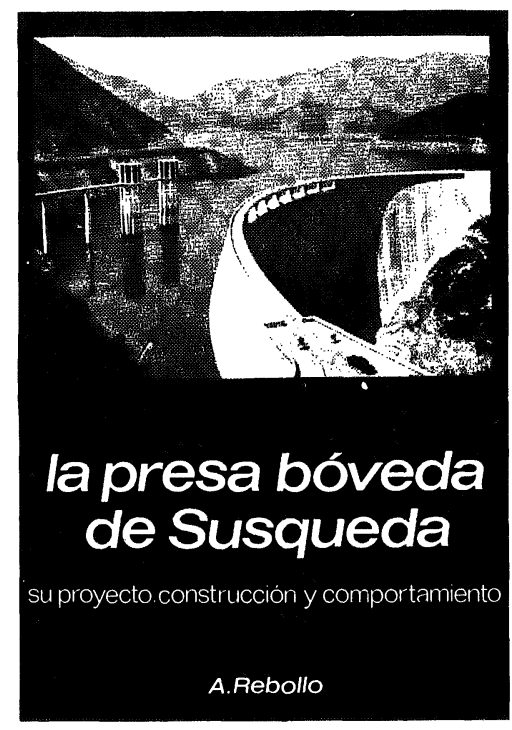

La presa bóveda de Susqueda

A. Rebollo,

Dr. Ingeniero de Caminos

El esfuerzo del constructor de presas se situa por su pretensión de perennidad, a contracorriente de las prendencias de pa civilzacion actual, caractegrandes presas en funcionamiento o en constuccion que gerontológicos para ma y reclaman los cuidados gervicio $y$ cos para mantener y perteccionar su perennidad. En la medida en que todas nuevas obras, grandes o pequeñas, son portadoras de riesgos ecologicos $y$, a veces, catastróficos, que aumentan con el envejecimiento, la gerontologia de las presas es todo un emplazo. La accion adelantada de Arturo Rebollo en este terreno marca un camino a seguir para todos los que aman su propia obra con la devoción paternal que el ha puesto en Susqueda.

Un volumen encuadernado en cartoné plastificado con lomo de tela, de $18 \times 24,5 \mathrm{~cm}$, compuesto de 408 páginas, 330 figuras y fotografias y 39 tablas. 